\title{
ANALISIS KEKUATAN UNSUR ITIKAD BAIK PADA PELAKSANAAN PENDAFTARAN MEREK DI INDONESIA (Studi Kasus Putusan Mahkamah Agung Nomor 364K/Pdt.Sus-HKI/2014) BERDASARKAN UNDANG-UNDANG NOMOR 20 TAHUN 2016
}

\author{
Wilson Wijaya \\ (Mahasiswa Program S1 Fakultas Hukum Universitas Tarumanagara) \\ (E-mail: wilsonsiwijaya@gmail.com)
}

\section{Christine S.T. Kansil}

(Corresponding Author)

(Dosen Hak Kekayaan Intelektual Fakultas Hukum Universitas Tarumanagara, Meraih Sarjana Hukum dari Fakultas Hukum Universitas Tarumangara, Magister Hukum dari Fakultas Hukum Universitas Tarumangara)

(E-mail: christinek_51170@yahoo.co.id)

\begin{abstract}
Brand is one part of intellectual property rights. Brand is an identifying mark that distinguishes one's property with another's property. However, there are many parties who have bad faith and want to be a part of other people brand's fame. So they use the same brand name in order to make the goods produced is well-known. Brand is regulated in law number 202016 about brand and Geographical Indication. Therefore we need to register our brand to avoid the parties who have bad faith. The authors want to discuss the issue of the strength of good faith element in the registration of trademarks in the implementation of registration in Indonesia and also the protection for brand holders whose registration are rejected in Indonesia. Author will use normative method and refer to scientific books. The strength of good faith element in registering can be seen in Article 4 of the Trademark and Geographical Indications. For protection, brand holder can register it in advance, if it has been approve, the brand holder can submit claim cancelation that regulated in Article 77 to the Central Jakarta District Court to be reviewed and decided who the trademark is and be prove who has the element of bad faith. It is suggested that the original trademark owner's to register their trademark at brand office Indonesia. For foreign trademark owner, they can also improve their trademark to be a well-known brand.
\end{abstract}

Keywords: Good Faith, Trademark, Protection, Bad Faith 


\section{PENDAHULUAN}

\section{A. Latar Belakang}

Pada era modern ini, perkembangan ilmu pengetahuan dan ilmu teknologi berkaitan erat dengan perkembangan Kekayaan Intelektual (KI). Perkembangan ini menjadi lebih cepat lagi seiring dengan perkembangan perdagangan internasional. Kekayaan Intelektual adalah hak kebendaan, hak atas sesuatu benda yang bersumber dari hasil kerja otak, hasil kerja rasio, hasil dari pekerjaan rasio manusia yang menalar. ${ }^{1)}$

Terdapat berbagai macam KI yang ada di Indonesia, yaitu Hak Cipta dan Hak Milik Industri. Dalam Hak Milik Industri terdapat Merek, Paten, Rahasia Dagang, Desain Industri, Desain Tata Letak Sirkuit Terpadu, Perlindungan Varietas Tanaman. Menurut Pasal 1 Ayat (1) UndangUndang Nomor 20 Tahun 2016 tentang Merek dan Indikasi Geografis, Merek adalah tanda yang dapat ditampilkan secara grafis berupa gambar, logo, nama, kata, huruf, angka, susunan warna, dalam bentuk 2 (dua) dimensi dan/atau 3 (tiga) dimensi, suara, hologram, atau kombinasi dari 2 (dua) atau lebih unsur tersebut untuk membedakan barang dan/atau jasa yang diproduksi oleh orang atau badan hukum dalam kegiatan perdagangan barang dan/atau jasa.

Dalam kehidupan sehari-hari pasti akan menemui merek, baik itu merek barang ataupun merek jasa. Merek adalah tanda yang dikenakan oleh pengusaha (pabrik, produsen, dan sebagainya) pada barang-barang yang dihasilkan sebagai tanda pengenal, cap (tanda) yang menjadi pengenal untuk menyatakan nama. ${ }^{2)}$ Merek adalah tanda pengenal yang membedakan milik seseorang dengan milik orang lain. ${ }^{3)}$ Merek sebagai

\footnotetext{
1) OK. Saidin, Aspek Hukum Hak Kekayaan Intelektual, (Jakarta: PT Raja Grafindo Persada, 2006), hal. 9.

${ }^{2)}$ Departemen Pendidikan dan Kebudayaan, Kamus Besar Bahasa Indonesia, (Jakarta: Balai Pustaka, 1976), hal.649.

3) Harsono Adisumarto, Hak Milik Intelektual Paten dan Merek, Cetakan ke-1, (Jakarta: Akademika Pressindo, 1989), hal.44.
} 
bagian dari Kekayaan Intelektual (KI) merupakan produk atau hasil dari proses atau kegiatan intelektual yang dilakukan oleh manusia. ${ }^{4)}$

Merek dibedakan menjadi dua yaitu merek jasa dan merek dagang. Menurut Pasal 1 Ayat (3) UU Merek No. 20 Tahhun 2016 tentang Merek dan Indikasi Geografis, Merek Jasa adalah merek yang digunakan pada jasa yang diperdagangkan oleh seseorang atau beberapa orang secara bersama-sama atau badan hukum untuk membedakan dengan jasa sejenis lainnya. Menurut Pasal 1 Ayat (2) UU Merek No. 20 Tahhun 2016 tentang Merek dan Indikasi Geografis, Merek Dagang adalah merek yang digunakan pada barang yang diperdagangkan oleh seseorang atau beberapa orang secara bersama-sama atau badan hukum untuk membedakan dengan barang sejenis lainnya. Menurut Pasal 1 Ayat (4) UU Merek No. 20 Tahhun 2016 tentang Merek dan Indikasi Geografis, Merek Kolektif adalah merek yang digunakan pada barang dan/atau jasa dengan karakteristik yang identik mengenai sifat, ciri umum, dan mutu barang atau jasa serta pengawasannya yang akan diperdagangkan oleh beberapa orang atau badan hukum secara bersama-sama untuk membedakan dengan barang dan/atau jasa sejenis lainnya. ${ }^{5)}$

Memasuki realita pasar, merek hadir dengan dua fungsi utama: sebagai tanda pembeda dan sebagai penunjuk asal barang. Kedua fungsi tersebut dijalankan secara paralel dan setara. Artinya, fungsi yang satu tidak melampaui peran yang lain dan secara fungsi tidak saling mengabaikan atau menegaskan. Dalam kerangka interaksi dan transaksi antara produsen dengan konsumen, merek memiliki peran mewakili produsen hadir di kawasan perdagangan dan membantu memudahkan konsumen mencirikan produk yang diinginkan atau menemukan barang yang diperlukan. ${ }^{6}$

\footnotetext{
4) Titon Slamet Kurnia, Perlindungan Hukum Terhadap Merek Terkenal di Indonesia pasca Perjanjian TRIPs, Cetakan ke-1, (Bandung: PT ALUMNI, 2011), hal.106.

5) Ibid,. hal.110.

6) Henry Soelistyo, Bad Faith Dalam Hukum Merek, Cetakan ke-2, (Yogayakarta: PT Maharsa Artha Mulia, 2017), hal. 7.
} 
Tujuan pemakaian merek adalah untuk memantapkan pertanggungjawaban pihak produsen atas mutu barang yang diperdagangkan. Selain dari itu, dimaksudkan untuk mengawasi batasbataas territorial perdagangan suatu jenis barang. ${ }^{7)}$

Merek sangat penting dalam dunia usaha, karena masyarakat merasa lebih nyaman untuk menggunakan suatu merek produk barang dan/atau jasa yang sudah memiliki reputasi dibandingkan dengan menggunakan merek suatu produk barang dan/atau jasa yang belum memiliki reputasi. Hal tersebut disebabkan karena masyarakat sebagai konsumen beranggapan bahwa suatu merek yang berkualitas, aman, dan bermutu untuk dikonsumsi disebabkan karena reputasi dari merek tersebut. Merek yang sudah memiliki reputasi, memiliki tingkat peminat yang lebih banyak di pasaran. Hal tersebut tentu cenderung memacu para produsen yang lain untuk bersaing dengan merek tersebut. ${ }^{8)}$

Suatu produk tanpa identitas atau merek dapat dipastikan akan menemui kesulitan dalam pemasaran, karena merek merupakan "penjual awal" bagi suatu produk untuk dijual kepada konsumen. Para konsumen membeli produk tertentu dengan melihat dari merek, karena menurut konsumen merek yang dibeli berkualitas tinggi dan aman untuk dikonsumsi disebabkan reputasi dari merek. ${ }^{9)}$

Dalam era perdagangan bebas seperti sekarang, merek merupakan suatu basis dalam perdagangan modern. Dikatakan basis, karena merek dapat menjadi dasar perkembangan perdagangan modern yang dapat digunakan sebagai goodwill, lambang kualitas, standar mutu, sarana menembus segala jenis pasar, dan diperdagangkan dengan jaminan guna menghasilkan keuntungan besar. Terdapatnya merek dapat lebih memudahkan konsumen membedakan produk yang akan dibeli oleh

\footnotetext{
7) Julius Rizaldi, Perlindungan Kemasan Produk Merek Terkenal Terhadap Persaingan Curang, Cetakan ke-1, (Bandung: PT Alumni, 2009), hal.2.

8) Ibid, hal.2-3.

9) Ibid,. hal.3.
} 
konsumen dengan produk lain sehubungan dengan baik kualitas, kepuasan, kebanggaan, maupun atribut lain yang melekat pada merek. ${ }^{10)}$

Negara Indonesia menganut sistem first to file yang berarti bahwa untuk memiliki hak atas suatu merek diperlukan pendaftaran. Sesuai Pasal 13 Juncto PerMenKumHam No. 67 Tahun 2016 Pasal 4 Ayat (1) Permohonan merek yang sudah melengkapi persyaratan minimum pendafaran merek, yaitu berupa formulir pendaftaran merek yang telah diisi lengkap, label merek dan bukti pembayaran biaya, maka akan diberikan tanggal penerimaan. Dalam jangka waktu paling lama 15 (lima belas) hari terhitung sejak tanggal penerimaan, Direktoral Jenderal akan melakukan pemeriksaan kelengkapan dokumen persyaratan pendaftaran merek atau sering disebut dengan pemeriksaan formalitas.

Harus diakui, asas itikad baik terasa lebih sulit diaktualisasikan dalam mekanisme pendaftaran merek berdasarkan sistem deklaratif, sebab, sesuai dengan sistem itu, seseorang dapat setiap saat mendeklarasikan diri sebagai pemilik merek tanpa mekanisme kontrol legalitas kepemilikan merek tersebut. Pengalaman Indonesia selama 30 tahun menggunakan sistem deklaratif mencatat banyak sekali deklarasi kepemilikan merek yang tidak sah. Merek yang dinyatakan diakui sebagai mereknya ternyata milik orang lain. Milik orang asing di luar negeri. Mereka menyiasati hukum, sebab, sistem deklaratif mengakui siapa yang pertama kali mendaftarkan mereknya di Indonesia, dialah yang akan diakui sebagai pemiliknya. Hak milik atas merek seperti itu selanjutnya dikukuhkan melalui permintaan pendaftaran di Kantor Merek. ${ }^{11)}$

Suatu merek yang memiliki reputasi atau terkenal (well-known mark), dapat memicu tindakan pelanggaran merek baik yang berskala nasional maupun yang berskala internasional. Apabila suatu merek sudah menjadi merek terkenal, tentunya hal tersebut dapat menimbulkan suatu permasalahan hukum, seperti munculnya para kompetitor yang beriktikad

\footnotetext{
10) Ibid,. hal.3.

${ }^{11)}$ Henry Soelistyo, Op.Cit., hal. 3.
} 
tidak baik untuk melakukan peniruan atau bahkan pembajakan atas suatu merek terkenal. Selain merugikan konsumen, pelanggaran atas merek juga dapat merugikan para produsen korban peniruan atas merek tersebut. ${ }^{12)}$

Maraknya kasus pelanggaran merek yang terjadi disebabkan karena semakin ketatnya tingkat persaingan usaha, salah satu pelanggaran merek yang terjadi adalah pelanggaran merek terhadap merek dagang asing yang sudah terkenal. Pelanggaran semacam ini dapat terjadi karena suatu merek dagang asing tersebut belum didaftarkan di Direktorat Jenderal KI, yang kemudian didaftarkan oleh kompetitor yang beritikad tidak baik. Hal tersebut berdampak pada pendaftaran pemilik merek yang sesungguhnya terganggu atau bahkan ditolak oleh Direktorat Jenderal KI karena dianggap serupa dengan merek yang sudah terdaftar sebelumnya.

Kasus seperti ini pernah terjadi di Indonesia dalam putusan pengadilan Nomor 364K/Pdt.Sus-HKI/2014, yakni yang terjadi pada merek dagang "Bodycology" untuk produk kecantikan milik Advanced Beauty Systems Inc berkedudukan di Suite 40057201 BJ Freeway, Dallas, Texas 75240 Amerika Serikat. Merek dagang "Bodycology" sudah terdaftar di Amerika sejak tahun 22 September 1992 serta di Uni Eropa. Advanced Beauty Systems Inc saat ingin mendaftarkan produknya di Indonesia pada 16 April 2011 tetapi ternyata pendaftarannya ditolak oleh kantor merek Direktorat Jenderal Hak Kekayaan Intelektual (HKI), disebabkan karena produk serupa dengan merek "Bodycology" sudah didaftarkan atas nama Sherly Nyolanda pada 17 Januari 2011, dengan nomor sertifikat No. IDM0000289450.

Selanjutnya dari itu, Advanced Beauty Systems Inc mengajukan gugatan ke Pengadilan Niaga Jakarta Pusat untuk menggugat Sherly Nyolanda yang telah memakai merek "Bodycology" yang pada umumnya sama, tetapi Putusan Pengadilan Niaga menolak gugatan yang diajukan oleh Penggugat. Setelah itu, Penggugat mengajukan kasasi ke Mahkamah

\footnotetext{
${ }^{12)}$ Julius Rizaldi, Op.Cit., hal.4.
} 
Agung dan Putusan Mahkamah Agung mengabulkan permohonan Penggugat.

Berdasarkan latar belakang masalah tersebut di atas, maka akan diteliti dan dituangkan dalam karya ilmiah yang berbentuk jurnal penulisan dengan judul "ANALISIS KEKUATAN UNSUR ITIKAD BAIK PADA PELAKSANAAN PENDAFTARAN MEREK DI INDONESIA BERDASARKAN UNDANG-UNDANG NOMOR 20 TAHUN 2016 (Studi Kasus Putusan Mahkamah Agung Nomor 364K/Pdt.Sus-HKI/2014)"

\section{B. Perumusan Masalah}

Berdasarkan dari latar belakang yang telah dipaparkan sebelumnya, maka dapat dirumuskan menjadi beberapa pokok masalah. Permasalahan yang akan dibahas yaitu:

1. Bagaimana kekuatan unsur itikad baik pada pelaksanaan pendaftaran merek terkenal di Indonesia berdasarkan UU No. 20 Tahun $2016 ?$

2. Bagaimana perlindungan hukum terhadap pemilik merek terkenal yang ditolak pendaftaran di Indonesia?

\section{PEMBAHASAN}

\section{A. Merek Pada Umumnya}

1. Ruang Lingkup Merek

Hak Kekayaan Intelektual terdiri dari jenis-jenis perlindungan yang berbeda, bergantung kepada objek atau karya intelektual yang dilindungi. Dalam perundingan Persetujuan Umum tentang Tarif dan Perdagangan (General Agreement on Tarrif and Trade/GATT), disebutkan bahwa Hak Kekayaan Intelektual terdiri dari: Hak Cipta dan hak-hak yang berkaitan, Merek, Indikasi Geografis, Desain Industri, Paten, termasuk Perlindungan Varietas Tanaman, Desain Tata Letak Sirkuit Terpadu, Perlindungan terhadap Informasi Dirahasiakan, dan 
Pengendalian Praktik Praktik Persaingan Curang Dalam Perjanjian Lisensi.

Dari pengelompokan di atas, HKI pada umumnya berhubungan dengan ciptaan dan invensi yang memiliki nilai komersial. Merek sebagai salah satu produk dari karya intelektual dapat dianggap suatu asset komersial suatu perusahaan, untuk itu diperlukan perlindungan hukum untuk melindungi karya-karya intelektualitas seseorang. Kelahiran merek diawali dari temuan-temuan dalam bidang hak kekayaan intelektual lain yang saling berkaitan. Seperti dalam merek terdapat unsur ciptaan, misalnya desain logo, desain huruf atau desain angka. Ada hak cipta dalam bidang seni, sehingga yang dilindungi bukan hak cipta dalam bidang seni, tetapi yang dilindungi adalah mereknya sendiri. $^{13)}$

2. Fungsi Merek

Direktorat Jenderal Hak Kekayaan Intelektual memaparkan fungsi merek sebagai berikut: ${ }^{14)}$

a. Sebagai tanda pengenal untuk membedakan produk perusahaan yang satu dengan yang lain (product identity).

b. Sebagai alat atau sarana promosi untuk berdagang (means of trade promotion).

c. Sebagai penunjukan asal barang atau jasa yang dihasilkan (source of origin).

d. Sebagai jaminan atas mutu barang atau jasa (quality guarantee).

e. Sebagai alat bukti kepemilikan atas merek.

3. Sistem Pendaftaran dan Prosedur Pendaftaran Merek di Indonesia

a. Sistem Pendaftaran Merek di Indonesia

Untuk memperoleh siapa yang berhak atas merek, tergantung sistem yang dianut oleh negara yang bersangkutan. Sistem-sistem tersebut biasanya dikenal dengan sistem konstitutif dan sistem

\footnotetext{
13) OK. Saidin, Op.Cit., hal. 254.

14) Direktorat Jenderal HKI, Buku Panduan Hak Kekayaan Intelektual (pertanyaan dan Jawabannya), (Jakarta: Ditjen HKI Depkeh \& HAM, 2000), hal. 42.
} 
deklaratif. Yang dimaksud dengan sistem konstitutif adalah hak atas merek tercipta atau diperoleh karena pendaftaran, sedangkan yang dimaksud dengan sistem deklaratif adalah hak atas merek tercipta atau diperoleh karena pemakaian pertama, walaupun tidak didaftarkan. $^{15)}$

b. Prosedur Pendaftaran Merek di Indonesia

Pendaftaran merek dilakukan berdasarkan Permohonan Merek dari pemiliki merek atau yang berhak atas merek atau melalui kuasanya. Permohonan untuk pendaftaran merek tersebut nantinya harus diajukan kepada menteri, baik secara elektronik maupun non elektronik dalam bahasa Indonesia. ${ }^{16)}$

Pada pasal 4 Ayat (2) juncto PerMenKumHam No. 67 Tahun 2016, Pasal 3 Ayat (2) permohonan merek yang diajukan baik secara elektronik maupun non elektronik harus menyertakan dokumendokumen pendukung yang dibutuhkan, yaitu sebagai berikut:

1) Tanggal, bulan dan tahun permohonan merek;

2) Nama lengkap, kewarganegaraan, dan alamat pemohon;

3) Nama lengkap dan alamat kuasa jika permohonan merek diajukan melalui kuasa;

4) Warna jika merek yang dimohonkan pendaftarannya menggunakan unsur warna;

5) Nama negara dan tanggal permintaan merek yang pertama kali dalam hal permohonan diajukan dengan Hak Prioritas; dan

6) Kelas barang dan/atau jasa serta uraian jenis barang dan/atau jenis jasa.

Sesuai Pasal 13 Juncto PerMenKumHam No. 67 Tahun 2016

Pasal 4 Ayat (1) Permohonan merek yang sudah melengkapi persyaratan minimum pendafaran merek, yaitu berupa formulir pendaftaran merek yang telah diisi lengkap, label merek dan bukti

\footnotetext{
${ }^{15)}$ Suyud Margono, Hak Milik Industri, (Bogor: Ghalia Indonesia, 2011), hal. 65.

16) Abdulkadir Muhammad, Kajian Hukum Ekonomi Hak Kekayaan Intelektual, (Bandung: PT Citra Aditya Bakti, 2001), hal. 121.
} 
pembayaran biaya, maka akan diberikan tanggal penerimaan. Dalam jangka waktu paling lama 15 (lima belas) hari terhitung sejak tanggal penerimaan, Direktoral Jenderal akan melakukan pemeriksaan kelengkapan dokumen persyaratan pendaftaran merek atau sering disebut dengan pemeriksaan formalitas.

Bagi permohonan merek yang baru memenui persyaratan minimum maka dalam jangka waktu paling lama 30 (tiga puluh) hari sejak tanggal penerimaan, pemohon merek atau kuasanya akan diberikan surat pemberitahuan untuk melengkapi persyaratan pendaftaran merek dalam jangka waktu paling lama 2 (dua) bulan terhitung sejak tanggal penerimaan surat pemberitahuan sesuai dengan Pasal 11 Ayat (2) Juncto PerMenKumHam No. 67 Tahun 2016 Pasal 10 Ayat (1), (2) dan (3). Bila dalam jangka waktu 2 (dua) bulan kelengkapan persyaratan tidak dipenuhi juga, maka menteri akan memberitahukan secara tertulis kepada pemohon atau kuasanya bahwa permohonan mereknya dianggap ditarik kembali sesuai dengan Pasal 12 Juncto PerMenKumHam No. 67 Tahun 2016 Pasal 10 Ayat (4).

Pasal 14 Juncto PerMenKumHam No. 67 Tahun 2016 Pasal 4 Ayat (2) dan (3) menjelaskan setelah melewati tahapan pemeriksaan formalitas, maka permohonan merek akan diumumkan oleh menteri dalam berita resmi merek dalam jangka waktu paling lama 15 (lima belas) hari sejak tanggal penerimaan. Masa pengumuman permohonan merek berlangsung selama 2 (dua) bulan dalam berita resmi merek yang akan diterbitkan secara berkala oleh menteri melalui sarana eletronik dan/atau non elektronik.

Tahap selanjutnya bagi permohonan merek yang telah melewati masa pengumuman selama 2 bulan yaitu pemeriksaan substantif. Dalam pemeriksaan substantif, permohonan merek akan diperiksa oleh pemeriksa merek berdasarkan ketentuan-ketentuan yang diatur dalam Pasal 20 dan Pasal 21 UU merek dan Indikasi Geografis yaitu 
pasal-pasal yang mengatur tentang merek yang tidak dapat didaftar dan ditolak.

Pada Pasal 24 Ayat (1) hasil pemeriksaan substantif oleh pemeriksa merek dapat berupa permohonan merek yang dapat didaftar dan permohonan merek yang ditolak pendaftarannya. Apabila pemeriksa merek memutuskan permohonan merek dapat didaftar, maka menteri akan:

1) Mendaftarkan merek tersebut;

2) Memberitahukan pendaftaran merek tersebut kepada pemohon atau kuasanya;

3) Menerbitkan sertifikat merek; dan

4) Mengumumkan pendaftaran merek tersebut dalam berita resmi merek, baik elektronik maupu non elektronik.

4. Pengalihan Hak Atas Merek, Penghapusan dan Pembatalan

a. Pengalihan

Pada Pasal 41 UU Merek Nomor 20 Tahun 2016 menyebutkan bahwa peralihan hak atas merek dapat beralhih atau dialihkan karena:

1) Pewarisan

2) Wasiat

3) Wakaf

4) Hibah

5) Perjanjian

6) Sebab lain yang dibenarkan oleh peraturan perundang-undangan

b. Penghapusan Pendaftaran Merek

Penghapusan Merek terdafar dapat diajukan oleh pemilik Merek atau kuasanya kepada menteri. Penghapusan Merek terdaftar atas prakarsa Menteri dapat dilakukan jika:

1) Memiliki persamaan pada pokoknya dan/atau keseluruhannya dengan Indikasi Geografis; 
2) Bertentangan dengan ideology negara, peraturan perundangundangan, moralitas, agama, kesusilaan, dan ketertiban umum; atau

3) Memiliki kesamaan pada keseluruhannya dengan ekspresi budaya tradisional, warisan budaya tak benda, atau nama atau logo yang sudah menrupakan tradisi turun temurun.

c. Pembatalan Pendaftaran Merek

Berdasarkan Pasal 76, Gugatan Pembatalan merek dapat dilakukan jika berdasarkan alasan yang terdapat dalam Pasal 20 dan/atau 21 yaitu tentang merek yang tidak dapat didaftarkan dan merek yang ditolak. Gugatan pembatalan dapat diajukan dalam jangka waktu 5 (lima) tahun terhitung sejak tanggal pendaftaran merek, tetapi jika terdapat unsur itikad tidak baik dan/atau merek yang bersangkutan bertentangan dengan ideology negara, peraturan perundang-undangan, moralitas, agama, kesusilaan, dan ketertiban umum, maka gugatan pembatalan dapat diajukan tanpa batas waktu.

5. Teori pelanggaran dalam Hukum Merek

Pada prinsipnya sesuai prinsip hukum merek, pelanggaran merek dapat dikategorikan dalam tiga area utama, yaitu: ${ }^{17)}$

a. Infringement that create of likelihood of conclusion as to source, sponsorship, affiliation, or connection. (Pelanggaran yang menyebabkan persamaan yang membingungkan mengenai sumber, sponsor, afiliasi, atau koneksi).

b. Counterfeiting that useof mark that is substantially indistinguishsble-required for treble damages and criminal prosecution. (Pemalsuan dengan penggunaan merek yang secara substansial tidak dapat dibedakan yang dipersyaratkan untuk pemulihan tiga kali lipat dari jumlah kerugian sebenarnya

17) Rahmi Jened, Hukum Merek (Trademark Law) dalam Era Globalisasi dan Integrasi Ekonomi, (Jakarta: Prenadamedia Group, 2015), hal. 311. 
sebagaimana dimungkinkan oleh peraturan perundang-undangan dan untuk penuntutan pidana).

c. Dilution that lessening of the capacity of a famous mark to identify and distinguish goods or services regardless of competition or likelihood of confusion. (Dilusi merek yang mengurangi kapastitas sebuah merek terkenal untuk mengidentifikasikan dan membedakan barang atau jasanya, terkait dengan persaingan atau persamaan yang membingungkan).

\section{Sanksi}

Ketentuan Pidana berdasarkan Undang-Undang Nomor 20 Tahun 2016 tentang Merek dan Indikasi Geografis menyebutkan bahwa:

a. Setiap orang yang dengan tanpa hak menggunakan merek yang sama pada keseluruhannya dengan merek terdaftar milik pihak lain untuk barang dan/atau jasa sejenis yang diproduksi dan/atau diperdagangkan, dipidana dengan pidana penjara paling lama 5 (lima) tahun dan/atau pidana denda paling banyak Rp2.000.000.000,00 (dua milyar rupiah)/

b. Setiap orang yang dengan tanpa hak menggunakan merek yang mempunyai persamaan pada pokoknya dengan merek terdaftar milik pihak lain untuk barang dan/atau jasa sejenis yang diproduksi dan/atau diperdagangkan, dipidana dengan pidana penjara paling lama 4 (empat) tahun dan/atau denda paling banyak Rp2.000.000.000,00 (dua milyar rupiah).

c. Setiap orang yang melanggar ketentuan sebagaimana dimaksud pada huruf (a) dan huruf (b), yang jenis barangnya mengakibatkan gangguan kesehatan, gangguan lingkungan hidup, dan/atau kematian manusia, dipidana penjara paling lama 10 (sepuluh) tahun dan/atau denda paling banyak Rp.5000.000.000,00 (lima milyar rupiah). 


\section{B. Teori tentang itikad baik}

1. Itikad baik (Good Faith)

Ketentuan Pasal 20 UUM Nomor 20 Tahun 2016 tersebut dapat dinyatakan bahwa dalam UUM, meskipun menganut sistem konstitutif, tetapi tetap asasnya melindungi pemilik merek yang beritikad baik. Hanya permintaan yang diajukan oleh pemilik merek yang beritikad baik saja yang dapat diterima untuk didaftarkan. Dengan demikian aspek perlindungan hukum tetap diberikan kepada mereka yang beritikad baik dan terhadap pihak lain yang beritikad tidak baik yang sengaja meniru atau tidak jujur mendaftarkan mereknya, dapat dibatalkan oleh Direktorat Merek Kekayaan Intelektual. Pengertian itikad tidak baik dalam pendaftaran merek juga dapat diartikan suatu tindakan yang disengaja untuk meniru dengan sengaja sebagian atau seluruhnya merek yang telah terdaftar sebelumnya dengan tujuan agar merek yang didaftarkan tersebut dapat menyamai kepopuleran merek yang ditiru tersebut untuk keuntungan pendaftar merek yang beritikad tidak baik tersebut. ${ }^{18)}$

Itikad tidak baik dalam suatu pendaftaran merek harus ditolak karena merupakan tindakan curang dari orang, beberapa orang secara bersama-sama atau badan hukum yang merugikan pemilik merek yang telah terdaftar sebelumya. Tindakan curang yang dilakukan oleh pendaftar merek dengan itikad tidak baik tersebut tidak dibenarkan dalam prinsip dasar pendaftaran merek di Indonesia. Dengan demikian dapat dikatakan itikad tidak baik dalam suatu pendaftaran merek dapat diklasifikasikan sebagai: ${ }^{19)}$

1) Tindakan atau perbuatan meniru merek yang telah terdaftar sebelumnya, dan pada umumnya adalah merek yang sudah terkenal dan memiliki nilai jual dipasaran

\footnotetext{
${ }^{18)}$ Edy Damian, Hak Kekayaan Intelektual, (Bandung: PT Alumni, 2006), hal. 49.

${ }^{19)}$ D Maulana, Perlindungan Merek Terkenal di Indonesia dari Masa ke Masa, (Bandung: Citra Aditya Bakti, 2005), hal. 72.
} 
2) Merupakan suatu perbuatan yang dengan sengaja dilakukan untuk menyaingi merek yang sudah terdaftar dan memiliki nilai dengan itikad tidak baik tersebut memperoleh keuntungan pribadi dengan tidak mempedulikan kerugian yang didertia oleh pemilik merek yang telah terdaftar sebelumnya tersebut yang ditirunya.

3) Tindakan pendaftaran merek dengan itikad tidak baik tersebut dengan sengaja telah melakukan perbuatan melawan hukum khususnya prinsip dasar pendaftaran merek dalam hal itikad baik dalam melakukan pendaftaran merek, sehingga konsekuensinya adalah merugikan merek yang telah terdaftar sebelumnya dan telah memiliki ketenaran serta nilai jual yang baik dipasaran.

\section{Itikad Tidak Baik (Bad Faith)}

Secara singkat, bad faith adalah perilaku atau tindakan yang mengandung motif yang berkebalikan dari tindakan yang mendasarkan pada prinsip utmost good faith. Bad faith adalah tindakan yang dilakukan dengan didasari niat buruk. Tindakan seperti itu lazimnya disertai dengan niat melakukan kecurangan, baik secara nyata maupun yang masih dalam tahap rencana. Tujuannya, untuk mengelabui atau menyesatkan pihak lain, atau dalam batas tertentu bermaksud mengabaikan atau mengelak dari kewajiban yang harus dipenuhinya. Selaras dengan kaidah ini, ketentuan klasik yang diatur dalam Pasal 1338 Ayat (3) KUH Perdata menekankan pula pentingnya prinsip itikad baik dalam membuat dan melaksanakan perjanjian. Intinya kontrak harus dibuat dan dilaksanakan atas dasar itikad baik. ${ }^{20)}$

\section{Teori Perlindungan Kekayaan Intelektual}

\section{Teori Perlindungan Kekayaan Intelektual}

Merek sebagai bagian dari Kekayaan Intelektual merupakan aset yang harus dilindungi. Dalam hal ini, terdapat beberapa teori mengenai perlindungan KI seperti: ${ }^{21)}$

\footnotetext{
20) Ibid., hal. 34.

21) Julius Rizaldi, Op.Cit., hal. 38.
} 
a. Teori Reward

b. Teori Recovery

c. Teori Incentive

d. Teori Expanded Public Knowledge

e. Teori Risk

f. Teori Public Benefit

D. Kekuatan Unsur Itikad Baik Pada Pelaksanaan Pendaftaran Merek Terkenal di Indonesia Berdasarkan Undang-Undang Nomor 20 Tahun 2016

Indonesia menganut sistem konstitutif atau disebut sebagai First to file yaitu hak atas merek tercipta atau diperoleh karena pendaftaran. Di Indonesia tidak menganut sistem Deklaratif yang memiliki arti hak atas merek diperoleh berdasarkan pemegang atau pembuat pertama atas suatu merek tersebut. Kedua sistem tersebut memiliki kelemahan dan kelebihan masing-masing. Sistem konstitutif memiliki kelebihan lebih akurat bagi para pemilik merek dagang yang ingin mendaftarkan mereknya untuk diberikan perlindungan hukum oleh Undang-Undang Merek, sedangkan kekurangannya yaitu banyak pihak yang sengaja mendaftarkan merek dagang hanya untuk mendapatkan keuntungan dan mendapatkan perlindungan dari Undang-Undang Merek. Sistem Deklaratif memiliki kelebihan yaitu pemegang pertama dapat dilindungi asalkan dapat membuktikan bahwa dia adalah pemegang pertama, tetapi kekurangannya adalah untuk jaman sekarang ini sangat sulit untuk membuktikannya karena banyak memakan waktu untuk membuktikannya.

Dilihat dari sistem yang dianut oleh Indonesia, banyak pihak yang memiliki itikad tidak baik dalam melakukan pendaftaran karena dalam Undang-Undang Merek, perlindungan diberikan bagi pihak yang telah mendaftarkan merek. Tentu saja akan membuka peluang bagi pihak yang memiliki itikad tidak baik untuk melakukan pendaftaran, apalagi jika pihak tersebut mengetahui ada merek yang mulai berkembang belum didaftarkan di kantor merek 
Dalam Undang-Undang Merek No. 20 Tahun 2016 tentang Merek dan Indikasi Geografis tidak dijelaskan secara rinci mengenai pendaftaran yang memiliki itikad baik. Dalam Undang-Undang Merek hanya menjelaskan syarat dan tata cara permohonan yang dicantumkan dalam Pasal 4 Ayat (2) juncto PerMenKumHam No. 67 Tahun 2016, Pasal 3 Ayat (2) permohonan merek yang diajukan baik secara elektronik maupun non elektronik harus menyertakan dokumen-dokumen pendukung yang dibutuhkan, yaitu sebagai berikut:

1. Tanggal, bulan dan tahun permohonan merek;

2. Nama lengkap, kewarganegaraan, dan alamat pemohon;

3. Nama lengkap dan alamat kuasa jika permohonan merek diajukan melalui kuasa;

4. Warna jika merek yang dimohonkan pendaftarannya menggunakan unsur warna;

5. Nama negara dan tanggal permintaan merek yang pertama kali dalam hal permohonan diajukan dengan Hak Prioritas; dan

6. Kelas barang dan/atau jasa serta uraian jenis barang dan/atau jenis jasa.

Dalam melakukan pendaftaran yang benar yaitu harus sesuai dengan prosedur yang berlaku yaitu harus sesuai dengan Pasal 4. Jika pemilik merek dagang telah melengkapi semua syarat dan tata cara permohonan pendaftaran, maka dapat dikatakan bahwa pendaftar memiliki itikad baik dalam melakukan pendaftaran.

Dalam kasus Bodycology, penilaian atas merek bodycology merupakan merek terkenal atau tidak harus ditinjau lebih dahulu karena berdasarkan putusan Mahkamah Agung tidak memutuskan bahwa merek Bodycology merupakan merek terkenal, tetapi merek bodycology telah memenuhi salah satu unsur atau kriteria yaitu telah didaftarkan di beberapa negara. Penulis berpendapat bahwa merek tersebut merupakan merek terkenal karena sudah memenuhi beberapa kriteria yaitu jangkauan daerah penggunaan merek dan pendaftaran merek atau permohonan merek di negara lain 
Penulis tidak setuju dengan putusan Pengadilan Negeri yang mengganggap bahwa merek bodycology bukan merupakan merek terkenal karena untuk merek bodycology telah memenuhi beberapa unsur atau kriteria merek terkenal. Penulis berpendapat bahwa merek bodycology merupakan merek terkenal sehingga tergugat telah melakukan pendaftaran dengan itikad tidak baik dan sudah sepatutnya DJKI menolak permohonan pendaftaran yang dilakukan oleh Sherly Nyolanda selaku tergugat.

Merek memiliki hubungan yang erat dengan persaingan yang tidak jujur. Persaingan yang tidak jujur ini dapat berupa upaya untuk mendompleng ketenaran suatu merek terkenal. Tindakan ini akan berdampak kepada pemilik merek dagang atau merek terkenal. Penjelasan itikad tidak baik juga dapat diartikan sebagai kebalikan dari pengertian itikad baik.

Kekuatan unsur itikad baik dalam pelaksanaan pendaftaran di Indonesia sangatlah lemah karena kantor merek tidak dapat menolak permohonan pendaftar merek jika telah memenuhi semua syarat dan ketentuan yang ada dalam Pasal 4. Dari segi hukum, itikad baik dalam pelaksanaan pendaftaran merek hanya diatur di dalam Penjelasan Pasal 4 UU Merek Nomor 15 Tahun 2001 Juncto UU Merek yang baru yaitu terdapat pada Pasal 21 Ayat (3) UU Merek Nomor 20 Tahun 2016. Jadi kekuatan unsur itikad baik seseorang tidak dapat dibuktikan saat melakukan pendaftaran merek tetapi dapat dibuktikan saat ada pihak lain yang ingin mendaftarkan merek itu, barulah akan dilanjutkan dengan memberikan gugatan kepada Pengadilan Negeri Jakarta Pusat. Kasus ini sama dengan kasus merek Bodycology dimana penggugat yang ingin mendaftarkan mereknya lalu ditolak oleh kantor merek karena sudah ada yang mendaftarkan merek bodycology terlebih dahulu, kemudian pengadilanlah yang akan membuktikan adanya unsur itikad tidak baik yang dilakukan seseorang. 


\section{E. Perlindungan Hukum Terhadap Pemilik Merek Yang Ditolak Pendaftarannya di Indonesia}

Dalam dunia perdagangan, setiap pengusaha baik subjek hukum maupun badan hukum pasti memiliki ciri khas untuk barang atau produk yang diproduksinya. Ciri khas yang dimiliki pengusaha ini kita kenal dengan merek. Merek digunakan untuk menjadi pembeda antara suatu merek yang satu dengan merek lainnya.

Pengusaha yang baru membuat atau baru memulai untuk membuka usaha, akan membuat merek supaya dapat dikenal dan menjadi pembeda. Lalu, pengusaha pasti akan berusaha agar merek tersebut dapat dikenal masyarakat. Letak masalah yang sering timbul dalam dunia merek adalah banyak pengusaha yang mengambil jalan pintas atau jalur cepat untuk mendompleng atau menaikkan nilai suatu merek dengan cara menumpang merek yang sudah terkenal. Cara yang diambil oleh pengusaha tersebut akan merugikan pihak lain terutama pemilik asli merek yang sudah bersusah payah membuat mereknya menjadi merek terkenal.

Dalam Undang-Undang Merek Nomor 20 Tahun 2016 tentang Merek dan Indikasi Geografis menyatakan bahwa Indonesia menganut sistem Konstitutif atau First to file yang diatur dalam Pasal 3 yang berbunyi Hak atas merek diperoleh setelah Merek tersebut terdaftar. Bagi merek yang belum terdaftar, tidak mendapatkan hak atas merek tersebut. Setelah mendapatkan hak atas merek, barulah mendapatkan perlindungan oleh Undang-Undang Merek dan Indikasi Geografis ini.

Perlindungan merek biasa atau yang belum terkenal hanya dapat dilakukan jika pemilik merek telah mendaftarkan mereknya. Jika merek belum terdaftar, maka perlindungan yang diberikan oleh Undang-undang merek yaitu dengan mengajukan gugatan pembatalan terhadap pendaftar merek yang beritikad tidak baik.

Perlindungan merek terkenal berbeda dengan perlindungan merek biasa karena perlindungan merek terkenal lebih pasti karena menurut hasil wawancara dengan pakar hukum merek, saat pendaftar merek ingin 
melakukan pendaftaran suatu merek, Direktorat Jenderal Kekayaan Intelektual melakukan pemeriksaan terhadap seluruh merek yang sudah menjadi terkenal. Jika DJKI menemukan adanya kesamaan pada pokoknya maupun kesamaan pada keseluruhannya, maka DJKI akan langsung menolak pendaftaran tersebut karena pendaftar memiliki itikad tidak baik.

Kasus bodycology menurut putusan pengadilan niaga maupun putusan Mahkamah Agung merupakan merek biasa tetapi menurut penulis, merek bodycology sudah dapat dikatakan sebagai merek terkenal karena telah melengkapi salah satu kriteria atau unsur untuk dapat dikatakan sebagai merek terkenal yaitu telah didaftarkan di beberapa negara uni eropa. Pada putusan pengadilan niaga, penggugat yang merupakan pemilik merek asli atau pemilik merek bodycology terlebih dahulu dikalahkan oleh hakim pengadilan niaga karena tidak menemukan unsur itikad tidak baik yang dilakukan tergugat. Penggugat melakukan langkah-langkah untuk merebut kembali merek yang sudah diproduksi sejak tahun 1992 yaitu mengajukan gugatan pembatalan kepada Pengadilan Niaga Jakarta Pusat tetapi gugatan tersebut ditolak oleh hakim Pengadilan Jakarta Pusat. Penggugat mengambil langkah lebih lanjut yaitu melakukan kasasi dan hakim Mahkamah agung memenangkan Penggugat dan mengadili bahwa merek bodycology merupakan milik penggugat

Gugatan pembatalan dan Gugatan Penghapusan memiliki perbedaan dalam pelaksanaanya. Gugatan pembatalan dapat dilakukan jika merek tersebut masih dilakukan oleh pihak lain dan masih melakukan produksi, perdagangan dan peredaran, sedangkan gugatan penghapusan dapat dilakukan jika merek tersebut tidak digunakan atau diproduksi secara berturut-turut selama 3 tahun terakhir setelah tanggal pendaftaran. Ini sesuai dengan Pasal 74 Ayat (1) Undang-Undang Nomor 20 Tahun 2016 Tentang Merek dan Indikasi Geografis.

Untuk merek Bodycology, penggugat telah benar melakukan gugatan pembatalan karena merek Bodycology masih dipakai, dipergunakan, diproduksi, diperdagangkan, maupun didistribusikan di wilayah Indonesia. 
Gugatan Pembatalan tidak dapat diajukan jika telah melebihi jangka waktu yang telah diatur dalam Pasal 77 Undang-Undang Nomor 20 Tahun 2016 tentang Merek dan Indikasi Geografis yaitu batas waktu untuk mengajukan gugatan pembatalan adalah 5 (lima) tahun sejak tanggal pendaftaran merek. Penggugat masih berada dalam jangka waktu tersebut karena tanggal pendaftaran yang dilakukan oleh tergugat adalah pada tanggal 17 Januari 2011 sedangkan Penggugat mengetahui pendaftaran tersebut karena penggugat juga melakukan pendaftaran pada tanggal 16 April 2011 dimana hanya memiliki selang waktu selama 3 bulan.

Berdasarkan Pasal 84 Undang-Undang Merek Nomor 20 Tahun 2016 menyatakan bahwa penggugat dapat meminta hakim untuk menghentikan kegiatan produksi, peredaran, dan/atau perdagangan barang dan/atau jasa yang menggunakan merek tersebut untuk mengurangi kerugian yang lebih besar yang diderita oleh pemilik merek asli.

Jika Merek Bodycology dianggap sebagai merek terkenal, maka lebih mudah untuk penyelesaiannya tanpa melalui jalur hukum. Sesuai dengan Pasal 21 Ayat (3), maka sudah sepatutnya saat tergugat melaksanakan pendaftaran, DJKI langsung menolak merek Bodycology. Jika DJKI melakukan kesalahan dalam pengecekan terhadap merek terkenal, maka DJKI akan membantu pemilik merek dagang tersebut untuk mendaftarkannya terlebih dahulu. Tujuan pendaftaran ini dilakukan dengan tujuan agar pemilik dagang pertama atau asli ini dapat mengajukan gugatan kepada tergugat atau pihak yang memiliki itikad tidak baik,

Penulis menganggap bahwa perlindungan terhadap merek biasa tidak efektif dan menimbulkan penumpukan perkara dan kerugian yang lebih yang ditanggung baik pemilik merek asli maupun pengadilan. Penulis berharap agar pemerintah dapat membuat peraturan khusus untuk pendaftar yang memiliki itikad tidak baik untuk melindungi pemilik pertama dan dapat memberikan sanksi yang tegas agar pihak yang beritikad tidak baik mendapatkan efek jera dan tidak mengulanginya kembali. Perlindungan ini bertujuan agar pemilik merek asing maupun 
nasional merasa aman, terlindungi dan tidak menimbulkan kerugian yang lebih dan tidak membuang waktu.

\section{Penutup}

\section{A. Kesimpulan}

Berdasarkan pembahasan permasalahan pada bab sebelumnya maka dapat dikemukakan kesimpulan sebagai berikut:

1. Kekuatan itikad baik dalam pelaksanaan pendaftaran merek di Indonesia tidak ada takaran untuk menentukan itikad tidak baik dalam pendaftaran karena setiap pendaftar dianggap memiliki itikad baik selama semua persyaratan yang ada dalam Undang-Undang Merek Nomor 20 Tahun 2016 tentang Merek dan Indikasi Geografis telah dipenuhi. Tidak ada alasan bagi DJKI untuk menolak pendaftar yang telah memenuhi semua persyaratan yang dituangkan dalam Pasal 4, 5 dan 6. Sehingga kekuatan unsur itikad baik dalam pendaftaran merek masih sangat lemah.

2. Perlindungan hukum yang diberikan kepada pemilik merek dagang yang diberikan oleh pemerintah memang sudah ada, namun belum efektif karena masih hanya sebatas perlindungan secara represif. Memang hal ini merupakan hal yang sulit mengingat bahwa terdapat berbagai pihak yang masih sangat sulit untuk meningkatkan mereknya menjadi merek terkenal.

Memang pemerintah yang memegang tanggung jawab terhadap penjaminan, memenuhi dan menegakan hak asasi manusia dalam hal ini perlakuan menumpang pada merek orang lain untuk mencari ketenaran, namun kita harus melihat faktor lain yang menyebab terjadinya pendaftaran merek dagang milik pihak lain, yang menjadi faktor lainnya adalah karena belum tersedianya peraturan khusus tentang perlindungan tehadap merek biasa.

Hal ini disebabkan karena minimnya kesadaran hukum yang dimiliki oleh seluruh elemen masyarakat, karena budaya yang tercipta sudah 
memiliki stigma yang buruk terhadap merek terkenal, hal ini yang menimbulkan perbuatan pendaftaran itikad tidak baik makin banyak terjadi terutama bagi merek yang belum didaftarkan apalagi merek tersebut merupakan merek dagang asing.

\section{B. Saran}

Berdasarkan kesimpulan di atas, maka saran yang dapat diberikan adalah sebagai berikut:

1. Bagi Pemerintah sebaiknya dapat mempertimbangkan bahwa aturan mengenai pendaftaran itikad tidak baik harus diperkuat agar untuk kedepannya tidak ada yang berani mendaftarkan merek orang lain untuk kepentingan dan keuntungan dirinya sendiri.

2. Bagi masyarakat yang baru memiliki merek, sebaiknya dapat langsung mendaftarkan merek ke kantor merek untuk menghindari pihak yang beritikad tidak baik yang melakukan perdagangan merek.

3. Bagi Direktorak Jenderal Kekayaan Intelektual untuk dapat memperketat pendaftaran merek, dan menolak pendaftaran merek jika mendaftarkan lebih dari satu merek dan menambahkan unsur untuk menyertakan bukti bahwa merek tersebut adalah produksi diri sendiri, bukan mendatangkannya secara import dan menjualnya kembali.

\section{DAFTAR PUSTAKA}

\section{A. Buku-Buku}

Chazawi, Adami. Tindak Pidana Hak Atas Kekayaan Intelektual, (Malang: Bayu Media, 2007).

Damian, Edy. Hak Kekayaan Intelektual, (Bandung: PT Alumni, 2006).

Diantha, I Made Pasek. Metodologi Penelitian Hukum Normatif Dalam Jutifikasi Teori Hukum. (Jakarta: Kencana Prenada Media Group, 2016).

Jenie, Ismijati. Itikad Baik Sebagai Asas Hukum, (Yogyakarta: Pascasarjana UGM, 2009).

Kurnia, Slamet Titon.Perlindungan Hukum Terhadap Merek Terkenal di Indonesia Pasca Perjanjian TRIPs. (Bandung: Alumni,2011). 
Maulana, D. Perlindungan Merek Terkenal di Indonesia dari Masa ke Masa, (Bandung: Citra Aditya Bakti, 2005).

Margono, Suyud. Aspek Hukum Komersialisasi Aset Intelektual. (Bandung: Nuansa Mulia, 2010).

Margono, Suyud. Hak Milik Industri. (Bogot: Ghalia Indonesia, 2011).

Marzuki, Peter Mahmud. Penelitian Hukum. Cetakan ke-9. Edisi Revisi. (Jakarta: Kencana PrenadaMedia Group, 2016).

Meliala, Syamsudin Qirom. Pengertian Asas Itikad Baik di Dalam Hukum Indonesia, (Surabaya: Mitra Ilmu, 2007).

Rizaldi, Julius. Perlindungan Kemasan Produk Merek Terkenal Terhadap Persaingan Curang, Cetakan ke-1, (Bandung: PT Alumni, 2009).

Roisah, Kholis. Konsep Hukum Hak Kekayaan Intelektual. (Malang: Setara Press, 2015).

Saidin, OK. Aspek Hukum Hak Kekayaan Intelektual. (Jakarta: PT Raja Grafindo Persada, 2006).

Saidin, OK. Aspek Hukum Hak Kekayaan Intelektual (Intelectual Property Rights), (Jakarta: Rajawali Pers, 2010).

\section{B. Peraturan Perundang-Undangan}

Indonesia. Undang-undang Nomor 20 Tahun 2016 tentang Merek dan Indikasi Geografis. (Lembaran Negara Republik Indonesia Tahun 2016 Nomor 5953).

\section{Artikel}

Anonim

Merek

Terkenal,

http://www.hukumonline.com/klinik/detail/lt5563c921eed12/iniperbedaan-merek-biasa-merek-terkenal-dan-merek-termasyhur , 20 Februari 2017.

Anonim, "Pengertian Kekuatan" https://www.gallupstrengthscenter.com/help/idid/faq-item/genfaq19?type=GEN

Anonim, "Pengertian Itikad Baik" http://www.definisimenurutparaahli.com/pengertian-itikad-baik/

Anonim, "Pengertian Pendaftaran" https://www.apaarti.com/pendaftaran.html , 24 April 2018. 


\section{Kamus}

Departemen Pendidikan dan Kebudayaan, Kamus Besar Bahasa Indonesia, Edisi Kedua, (Jakarta: Balai Pustaka, 1995). 